\title{
Cognitive Science Concepts and Technology Teacher Education
}

In theearly 1990s, Johnson (1992a) stated that technology educators had shown little interest in cognitive science-based research which heobserved was unfortunate because of the close alignment between many concepts in cognitive science and technology education. That may beless truetoday, but thedisconnect between being aware of these concepts and/or terms and teaching students to be able to consciously use these constructs to enhance learning is still apparent. It also appears that there is very little research on these cognitive science theories within the context of technology teacher education or technical education in general.

This article explores technology teacher educators' perceptions about and use of the following cognitive science theories: schemata, mental and graphic visualization, reflection and debriefing, situated learning or cognition, cognitive apprenticeship and itscomponent parts modeling, coaching and scaffolding, and metacognition. These theories are followed by a discussion of a survey of a selected group of teacher educators. The survey focused on thre questions:

1. How important do technology education teacher educators believe each of the identified cognitive science concepts are for inclusion in the preparation of preservice technology education teachers?

2. To what level do preservice teachers learn about or develop skills in each of these cognitive science concepts in preservice technology education teachers programs?

3. To what extent are these cognitive science concepts model ed and integrated intoclassroom instruction for preservice teachers?

The Theories

Cognition has been defined as coming to know. It includestheinternal mental processes of learning, perception, comprehension, thinking, memory, and attention and is grounded in an evolutionary shift in the psychology of learning from behaviorist to cognitivefocus (West, Farmer, \& Wolff, 1991). Cognitive science developed a social constructivist view of learning because it was learned that studentsactively incorporatesocial interaction and personal experience into the process of transforming information to knowledge (Johnson, 1992a). After examination of accessible cognitive science literature, I found theliteraturehighlighted the following learning theory-based concepts that seemed to relate directly or indirectly to experiential learning.

\section{Metacognition.}

M etacognition collectively consists of the becoming aware of personally preferred cognitive strategies as well as acquiring, employing, and monitoring new strategies for learning (J ohnson, 1992b; West et al., 1991). Also called strategic thinking, metacognition involves planning, regulating, and evaluating thinking activities. It includessuch strategiesasmonitoring, questioning, summarizing, predicting, generating, and evaluating alternatives. Knowledge is obtained through identification of relationships and connections. Experiential learning is necessarily personal and idiosyncratic (Burnard, 1988). $M$ etacognitive strategies are useful to the learner as he or she attempts to translate personal experienceto transferable learning.

\section{Schema Theory.}

People engage in information simplification to effectively manage their information processing requirements. Schema theory suggests that schemata areunconscious mental structures or models that underlie and control the simplifying process that is essential to human learning, skill acquisition, and problem solving (Johnson, 1992a; Phillips \& Lord, 1982; Satchwell, 1996; West et al., 1991). It has been suggested that schemata:

- reflect the individual's basic ideas about reality and relative importance;

- provide a framework for memory within which decisions can be made, operations performed, and new information retained;

- define understanding of how the world is organized and new information fits with previously acquired knowledge;

- provide structure to ambiguous or incomplete information;

- allow the individual to fill in missing data and edit information as it is retrieved from memory; and

- guide the information retrieval process (Brewer \& Nakamura, 1984; Kelley, 1972). Schemata are developed and information 
Table 1. Metacognition Related Responses.

\begin{tabular}{|c|c|c|c|}
\hline$\underline{\mathbf{n}}=29$ & 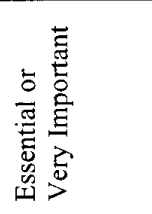 & 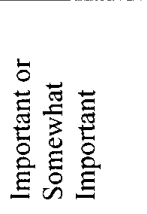 & 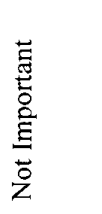 \\
\hline $\begin{array}{l}\text { Importance of knowledge of metacognition in technology } \\
\text { teacher education }\end{array}$ & $11-38 \%$ & $16-55 \%$ & $2-7 \%$ \\
\hline$\underline{\mathrm{n}}=31$ & 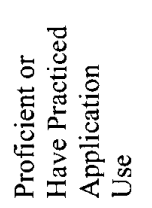 & 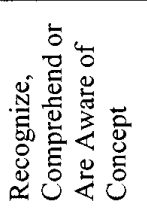 & 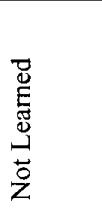 \\
\hline $\begin{array}{l}\text { Level of learning about metacognition by pre-service } \\
\text { technology education teachers }\end{array}$ & $7-23 \%$ & $17-54 \%$ & $7-23 \%$ \\
\hline$\underline{\mathrm{n}}=31$ & 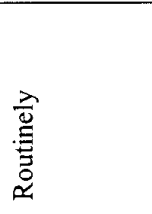 & 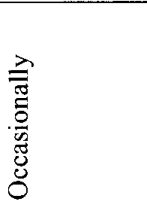 & 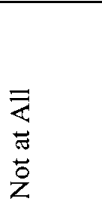 \\
\hline $\begin{array}{l}\text { To what extent is metacognition modeled or integrated by } \\
\text { faculty into instruction }\end{array}$ & $3-10 \%$ & $19-61 \%$ & $9-29 \%$ \\
\hline
\end{tabular}

is encoded and organized based upon the individual's first-hand experience as the individual retains and processes implicit and explicit teachings about the causal nature of the world, thus enabling persons to perform with limited information (Kelley, 1972). Preconceived causal beliefs influence not only interpretation of events and information, but also what information will be sought and how it will be used (Kelley \& M ichela, 1980; Wyer, 1981). These complex schema-based images exist in memory as perceptions of particular individuals, events, etc., or as prototypic perceptions (Wyer, 1981).

It is believed that people possess schemata of connected facts, skills, and strategies that help the individual explain and perform efficiently within his or her world. New information and/or experiences are interpreted through mental analysis based on comparison against existing relevant schemata. These schemata or mental models become the basis for interpretation of what actions are appropriate and which information may be assumed as well as learning and recall (Satchwell, 1996; West et al., 1991). Acknowledging preexisting schema changes the role of the technology teacher who wants to help students learn effectively through personal experience. Students must be encouraged to actively engage in activities that focus on examining causal relationships and comparing these relationships against their preexisting notions about technology and the world.

Visualization and Graphic Organizers.

Theterm chunking has been used to describe a broad array of organizing and simplifying strategies that aid in learning and analysis (West et al., 1991). M emory organization tools and aids to supplement limited working memory capacity such as those included under the umbrella of chunking havebeen shown to enable experts to recall enhanced volumes of information when needed to solve problems and transfer knowledge to new situations (Johnson, 1992a; Johnson \& Thomas, 1992). Chunking includes use of both graphic organizersand visual imagery.

Graphic organizers such as concept mapping and functional flow diagrams could be of particular interest to technology educators. Concept maps graphically simplify the display of concepts and the relationships between those concepts as a means of communicating, comprehending, and analyzing relationships of a physical system or body of knowledge. They have been shown to effectively act as mnemonic devices to help learners remember as well as aiding in analysis and understanding, troubleshooting, and problem solving. Providing or teaching learners to create simple conceptual diagrams helps students gain conceptual, holistic 
Table 2. Schema theory related findings.

\begin{tabular}{|c|c|c|c|}
\hline$\underline{\mathrm{n}}=29$ & 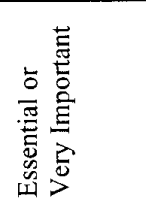 & 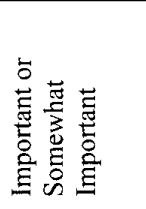 & 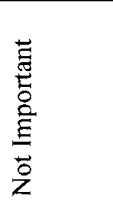 \\
\hline $\begin{array}{l}\text { Importance of knowledge of schema theory in technology } \\
\text { teacher education }\end{array}$ & $7-24 \%$ & $16-55 \%$ & $6-21 \%$ \\
\hline$\underline{\mathrm{n}}=31$ & 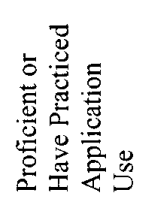 & 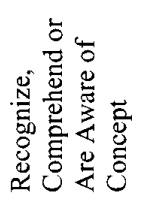 & 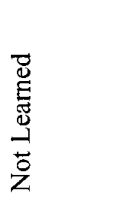 \\
\hline $\begin{array}{l}\text { Level of learning about schema theory by pre-service } \\
\text { technology education teachers }\end{array}$ & $4-13 \%$ & $18-58 \%$ & $9-29 \%$ \\
\hline$\underline{n}=31$ & 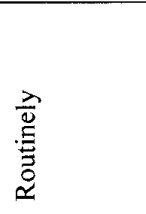 & 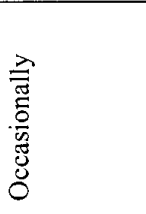 & $\begin{array}{l}\bar{\Xi} \\
\pm \\
0 \\
\vdots \\
\vdots\end{array}$ \\
\hline $\begin{array}{l}\text { To what extent is schema theory modeled or integrated by } \\
\text { faculty into instruction }\end{array}$ & $4-13 \%$ & $13-42 \%$ & $14-45 \%$ \\
\hline
\end{tabular}

understanding morequickly (Johnson, 1992a; Johnson \& Thomas, 1992; Satchwell, 1996; West et al., 1991). U se of simplified conceptual diagrams may improve overall system understanding, enhance ability to understand function and behavior of systems, enhance understanding of causal relationships, and improve learner ability to reconstruct conceptual models (deK leer \& Brown, 1981; Satchwell, 1996), or visual, coherent pictures that are less easily forgotten.

Visual imagery has long been used to teach drafting concepts as students were challenged to visualizeobjects mentally cultivating theability to rotate and section parts and assemblies as well as providing essential skills in invention and innovation based on design activities. M ore recently, visual practice has also been proposed as a method to provide low cost practice and enhancement of tasks requiring finemotor skills, high levels of eye-hand coordination, and with significant cognitive elements. This cognitive techniqueessentially consists of repeatedly thinking through a problem or processin a highly structured and disciplined manner (Whetstone, 1995).

\section{Reflection.}

Reflection has been described as "those intellectual and affective activities in which individuals engage to exploretheir experiences in order to lead to new understandings and appreciations" (Boud, Keough, \& Walker,
1985, p. 18). Few peoplecan convert personal experience to transferablelearning, principles, or models through the experience alone. H owever, the probability of thestudent making that transition is enhanced if the student is encouraged to focus, share, and reflect on the meaning of the experience, the connections between the experience and past experiences, theories, and/or generalizable models. Opportunities to reflect on and observe the meaning of experiences, then integrating those reflections and critical observations into personal theories, enhance the probability of transfer of learning to new contexts and situations (Burnard, 1988; Kolb, 1984).

Experiential learning has been described as having six distinct phases: planning, introduction, activity, debriefing, summary, and evaluation. In this model, the reflection or debriefing phase involves sharing and discussing the experience: its details, order, and meaning. This is the opportunity for participants to begin to make generalizable connections to prior learning and experiences (Walter \& M arks, 1981).

Reflection has been defined as the mental process of looking back over the completed experience and performance to assess and analyze, to make connections to convert experience into learning (Collins, 1989). The need for reflection too often becomes apparent 


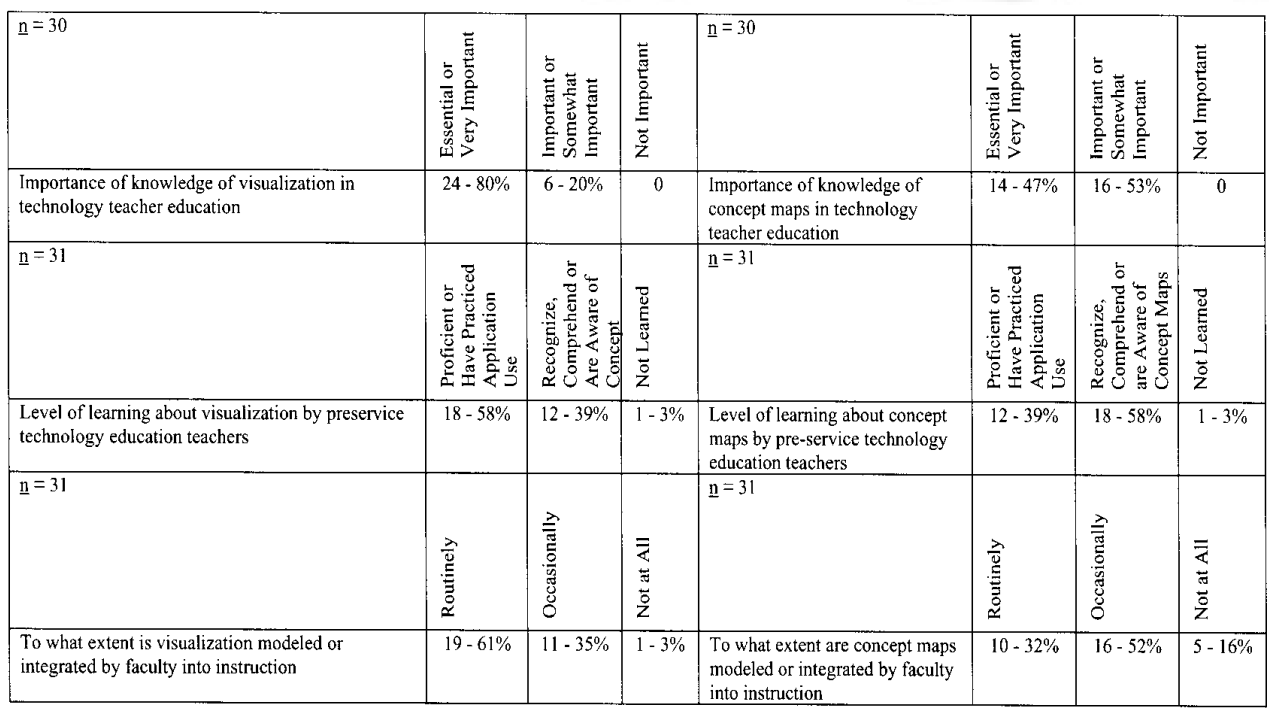

when students participate in classroom-based instructional experiences. $M$ any students seem to follow therecommended procedures but fail to grasp the significance of the event, the connections between their recent experience and relevant previously acquired knowledge (West et al., 1991). Reflection and articulation of ideas and thought as instructional practices enhance the ability to actively use and apply knowledge in other contexts (Schell \& Black, 1997). It has been these reflectiveor debriefing and summary phases that the author has observed are often overlooked when experiential learning activities have been observed in technology education laboratories.

\section{Situated Cognition/Learning.}

$K$ nowledge learned in context contains information about the conditions and constraints of its subsequent use. The context of learning impacts the learner'slater ability to recall the knowledge as well as understanding of the factors and conditions that are likely to accompany application of the learning and the ability to transfer it to new contexts (Johnson, 1992a; Johnson, 1995; West et al., 1991).

It is believed that situating learnersin social contexts where understanding is valued and socially acquired enhances the probability of transfer and application of that knowledge to contexts in the real $m$ of practice outside the classroom (Schell \& Black, 1997; Stern, 1998). Situated learning allows students to construct meaning from their experiences through doing. Students do not rely on segmented instruction structured and presented by instructors. The learning experience is problem or dilemma driven, not dictated by content structure. Instructional experiences are those that will be encountered at home, in the community, and in the workplace (Stern, 1998). The process of situated learning centers around three basic elements: (a) discovery and application of content; (b) the context, which defines likely futureuse and transfer; and (c) the community of practice, which joins analysis, reflection, and shared language that help achieve shared understanding (Stern, 1998).

Theideathat learning should begrounded in reality and practical application is not new (D ewey, 1938, 1956; Whitehead, 1929). It has long been believed that the context in which something is learned influences later use of that knowledge. Transfer of learning to useful contexts outside the classroom is an essential goal of technology education.

Cognitive Apprenticeship, Modeling Cognitive Proces, Coaching, and Scaffolding.

Cognitive apprenticeship is believed to providestructureto knowledgethrough creation of mental models and enhanced development of contextualized problem-solving processes. The cognitive apprenticeship is a metaphor for the modifying of classroom instructional techniques to incorporate aspects of traditional apprenticeship training approaches. In traditional apprenticeship models (a) work and doing are fundamental; (b) skills are developed beginning with easier, low-risk events and progressing to the more challenging; (c) the ability to know and do areinseparable; (d) standards of performance are 
Table 4. Reflection Related Responses.

\begin{tabular}{|c|c|c|c|}
\hline$\underline{\mathrm{n}}=29$ & 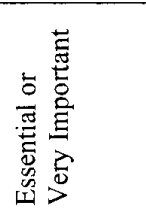 & 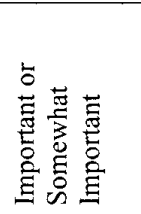 & 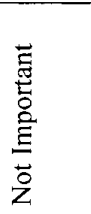 \\
\hline $\begin{array}{l}\text { Importance of knowledge of reflection in technology teacher } \\
\text { education }\end{array}$ & $14-48 \%$ & $15-52 \%$ & 0 \\
\hline$\underline{\mathrm{n}}=31$ & 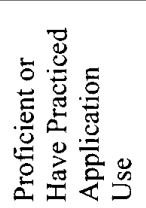 & 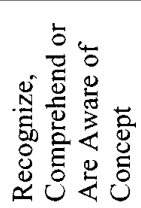 & 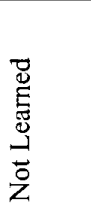 \\
\hline $\begin{array}{l}\text { Level of learning about reflection by preservice technology } \\
\text { education teachers }\end{array}$ & $11-35 \%$ & $19-61 \%$ & $1-3 \%$ \\
\hline$\underline{\mathbf{n}}=31$ & 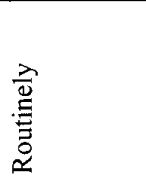 & 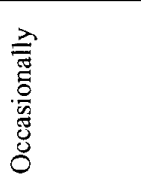 & $\begin{array}{l}\bar{z} \\
\vdots \\
\vdots \\
0 \\
\vdots \\
z\end{array}$ \\
\hline $\begin{array}{l}\text { To what extent is reflection modeled or integrated by faculty } \\
\text { into instruction }\end{array}$ & $11-35 \%$ & $18-58 \%$ & $2-6 \%$ \\
\hline
\end{tabular}

established by the community of practice; and (e) teaching is a support activity with guided practice and performance taking center stage (Berryman, 1999).

In the cognitive apprentice model four essential features prevail: application of content with cognitivestrategies imbedded, experiential methods, sequencing from the simple to the diverse and complex challenge, and the sociology of the community of practice. The focus is on individual and group problem solving situated in contexts that recreate realworld contexts using the instructional concepts of modeling, coaching, and scaffolding or fading while providing increasingly complex opportunities for learning (Berryman, 1999; Brown, Collins, \& Duguid, 1989; Cash, Behrmann, Stadt, \& D aniels, 1996; Collins, Brown, \& N ewman, 1989; West et al., 1991).

$M$ any of the skills peoplelearn throughout lifeareinitially acquired and enhanced through imitation. Modeling involves conscious verbalization by theinstructor of those internal cognitive strategies used by experts when solving complex problems and analyzing connections to existing knowledge. Cognitive modeling benefits students by making visible how experts approach problems by integrating skills and knowledge (Collins, 1989). For cognitive strategies to be acquired this way through modeling and imitation, theinstructor must not only exhibit the outward manifestations of learning, problem solving, and interacting but must al so makeexplicit the mental thought processes used. In this way cognitive strategies used by experts can be demonstrated, emphasized, and reinforced. This emphasis and reinforcement increases the probability of the strategies continued use (West et al., 1991).

Coaching involves providing "students a different perspective from which to understand their own performance" (Collins, 1989, p. 3). Traditional coaching techniques include demonstrating skills, offering hints, and providing formative feedback and reminders (Berryman, 1999; Brown et al., 1989). The effective coach provides only as much help as needed at critical times and focused on individual difficulties (Collins, 1989).

The term scaffol ding refers to management of type and intensity of instructional guidance provided by the instructor/mentor that is designed to aid the student in increasing competence and expertise through solution of increasingly ill-defined and complex problemsolving experiences. Thenovice is encouraged to practice problem-solving and complex skills under the direct supervision of the expert. As the novice develops expertise, supervision and oversight are gradually lessened, culminating in fading (agradual pulling back by theteacher) 


\begin{tabular}{|c|c|c|c|}
\hline$\underline{n}=31$ & 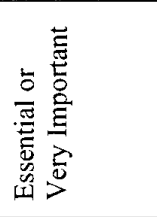 & 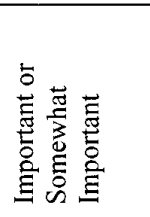 & 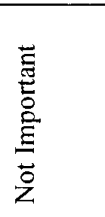 \\
\hline $\begin{array}{l}\text { Importance of knowledge of situated cognition in technology } \\
\text { teacher education }\end{array}$ & $23-74 \%$ & $8-26 \%$ & 0 \\
\hline$\underline{\mathrm{n}}=31$ & 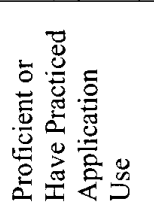 & 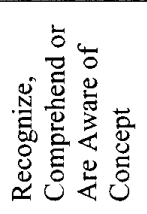 & 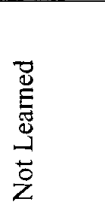 \\
\hline $\begin{array}{l}\text { Level of learning about situated cognition by preservice } \\
\text { technology education teachers }\end{array}$ & $14-45 \%$ & $11-35 \%$ & $6-20 \%$ \\
\hline$\underline{\mathrm{n}}=31$ & 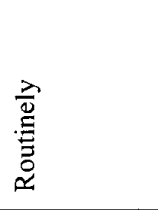 & 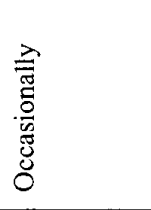 & $\begin{array}{l}\bar{z} \\
\vec{u} \\
\vec{o} \\
z\end{array}$ \\
\hline $\begin{array}{l}\text { To what extent is situated cognition modeled or integrated by } \\
\text { faculty into instruction }\end{array}$ & $15-48 \%$ & $10-32 \%$ & $6-20 \%$ \\
\hline
\end{tabular}

as the student assumes more control over the learning process until finally supervision is removed (Berryman, 1999; Brown et al., 1989; Stern, 1998; West et al., 1991).

An essential aspect of learning under the cognitive apprenticeship model is that the student explores the shared culture and language of the community of practice, reflecting upon and evaluating newly acquired skills and solutions in the context of community practice (Brown et al., 1989). In this way the cognitive processes of the novice can begin to emulate those of the expert.

\section{Views of the Constructs}

Sixty-five programs that reported three or moretechnology education undergraduates or three or more teachers certified in technology education in the 1998-1999 CTTE/N AITTE Industrial Teacher Education D irectory (Bell, 1998-1999) were contacted. Thirty-one instruments were completed and returned for a $50 \%$ response rate (after removing programs from the list that no longer offered technology teacher education). O nly simple descriptive statistics were used in analysis of data.

1. M etacognition. There was strong support for the importance of metacognition in technology teacher education. Thirty-eight percent (11) of the respondents described metacognition as essential or very important, and an additional $55 \%$ (16) indicated that it isimportant or at least somewhat important. Surprisingly, given this level of perceived importance, 23\% (7) of the programs said that the concept of metacognition was not taught to studentsin their programs. Further, $29 \%$ (9) indicated that faculty do not model or integrate metacognition into their instruction, and an additional $61 \%$ (19) indicated that thisconcept isonly occasionally modeled or integrated into instruction.

2. Schema Theory. Twenty-four percent (7) of the respondents identified knowledge of schema theory as essential or very important and 55\% (16) selected important or somewhat important in technology teacher education. This seems to indicate a strong (79\%) acceptance of the importance of understanding this theory. This is also supported by the 18 $(58 \%)$ programs which indicated that their students comprehend or are aware of schema theory and the additional programs where students practice or become proficient in use of schema theory. A question is raised by the responses that indicated that $87 \%$ (27) of these technology teacher education programs have faculty that model and/or integrate use of schema theory into instruction only occasionally or not at all. Teacher 


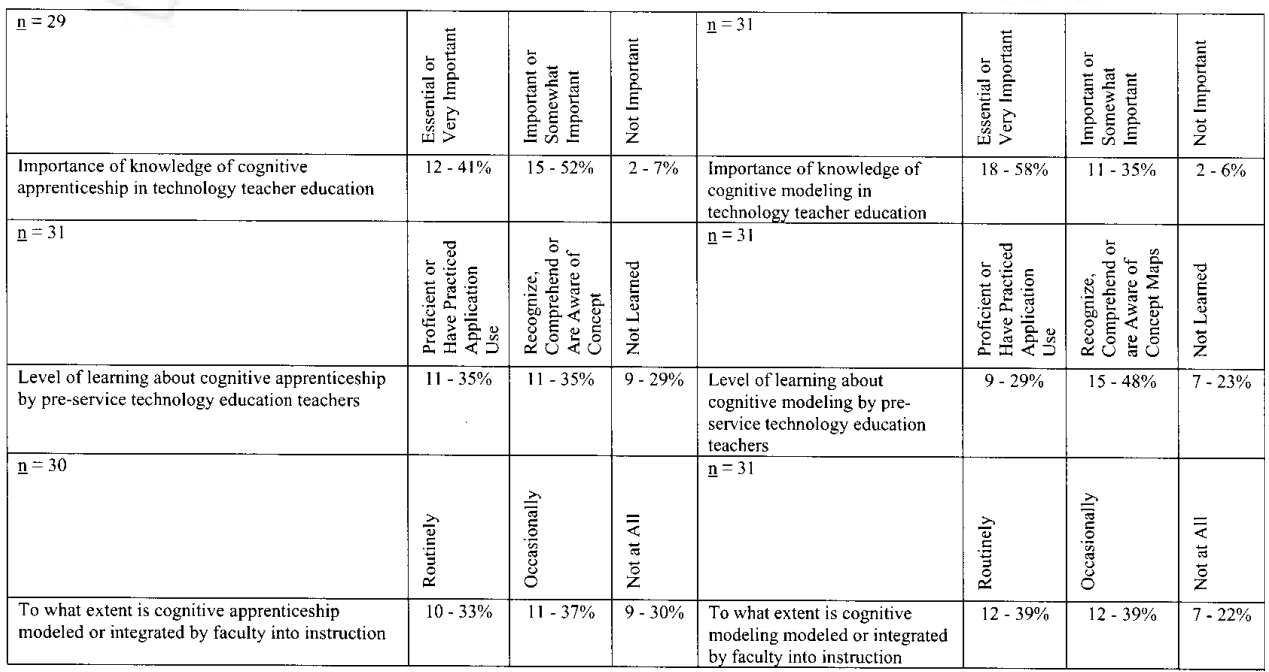

educators in our field arevery familiar with the disparity that often exists between a student's knowledge and his or her ability to apply that knowledge. If you accept theaxiom in instruction that teacherstend to teach as they were taught, this last finding makes one wonder about the likelihood that most new technology education teachers from these programs will incorporate this theory into their personal practice.

3. Chunking. Two questions focused on chunking related techniques such as visualization and graphic organizers, specifically concept maps. Support by teacher educators for the importance of knowledge of visualization was very strong with $80 \%$ (24) of the respondents describing it as essential or very important and the remaining $20 \%$ (6) describing it asimportant or somewhat important. This high level of perceived importance apparently is also reflected in practiceasinstruction is delivered to preservice teachers.

4. Visualization and Concept $M$ apping. Fiftyeight percent (18) of the students are reported to practice or become proficient in the use of visualization. This is further (routinely or occasionally) modeled or integrated into preservice teacher instruction by faculty in $96 \%$ (30) of the 31 programs reporting. Whilesupport for knowing about concept mapping was al so strong, it was surprisingly less strong than that expressed for visualization. O ne respondent indicated that knowledge of concept mapping was not important, and over one half (16 of 30 ) described it as important or only somewhat important. Similarly, 58\% (18) of the programs reported that studentslearn about concept mapping at only the comprehension, recognition, or awareness levels. Further use of concept maps is modeled or integrated into instruction by teacher education faculty only occasionally (52\%) or not at all (16\%) in $68 \%$ of reporting programs. This last finding was puzzling, considering the apparent support for knowing about concept maps and the usefulness of such tools in understanding, learning about, and troubleshooting technological systems. It appears that students come out of some technology education programs with knowledge of graphic organizers but little experience in using these useful tools.

5. Reflection. Technology teacher educators acknowledged theimportance of knowing about reflection as a tool to aid in transforming experience into learning. Forty-eight percent of the respondents described this concept as essential or very important in technology teacher education. An additional 52\% (15) classed it as important or somewhat important. Levels of learning about reflection by preservice teachers was reported similarly with $35 \%$ reporting that students practice or become proficient in application of reflection. Sixty-one percent (19) indicated that students achieve 
recognition, comprehension, or awareness levels of learning about reflection. The degree to which reflection was reportedly modeled or integrated into faculty instruction closely mirrored the levels of learning with this cognitive skill routinely modeled or integrated in 35\% (11) of the programs and occasionally modeled or integrated in $58 \%$ (18).

6. Situated Cognition or Learning. This concept was strongly supported as $74 \%$ (23) selected essential or very important to describe its importance in technology teacher education. The remaining respondents thought it important or at least somewhat important. O nce again, this overwhelming support for the importance of the concept does not necessarily translate into classroom instruction or experiences. Almost $20 \%$ (6) of the program representatives said that students do not learn about situated cognition in their teacher preparation. To further support this discrepancy, the same $20 \%$ said faculty did not model or integrate situated cognition into their instruction and an additional 32\% included it only occasionally.

7. CognitiveApprenticeship and Its $\mathrm{C}$ omponents. As before, there is strong support for the importance of including this into technology teacher education. Forty-one percent (12) identified it as essential or very important and an additional 52\% (15) classified this technique as important or at least somewhat important to our field. Again, support is not necessarily followed by action in teacher preparation. Twentynine percent (9) indicated that students in their programs do not learn about cognitive apprenticeship. Further, the samenumber indicated that faculty do not model or integrate cognitive apprenticeship into instruction and an additional $37 \%$ (11) indicated that it was included only occasionally.

The trend is mirrored in the data about cognitive modeling. Fifty-eight percent (18) of the program representatives indicated that knowledge of cognitive modeling as a teaching technique for technology education teachers is either essential or very important and an additional $36 \%$ (11) classified the technique as either important or at least somewhat important. Their perceptions of importance did not translate into student learning or instruction. Students in 23\% (7) of the programs do not learn about cognitive modeling as a teaching technique. In $23 \%$ of the reporting programs, cognitive modeling was neither modeled nor integrated into faculty instruction, and in an additional 39\% (12) this technique was only modeled or integrated occasionally by faculty.

$O$ verwhelming support exists for coaching as an instructional technique in technology teacher education. Fifty-eight percent (18) described knowledge of this concept as essential or very important and the remaining $42 \%$ described it as important or at least somewhat important to know about.

Scaffolding was afforded far less importance than coaching. Twenty-nine percent (9) of the respondents described scaffolding as essential or very important, but $19 \%$ (6) considered knowledge of this construct not important. This same disparity continued as participating teacher educators indicated that students in $42 \%$ of their programs do not learn about scaffolding as an instructional technique and $94 \%$ noted that faculty in their programs model or integrate scaffolding into instruction only occasionally $(55 \%)$ or not at all $(39 \%)$.

\section{The Questions in Light of the Survey Results}

What is the relationship between the experiential learning approach of technology education and the findings of cognitive science?

It has frequently been proposed that a technology education program should preparea technologically literate person with "the ability to use, manage and understand technology" (ITEA, 1996, p. 6). Similarly, Johnson (1992a) observed that effective technology education programs provide students with knowledge to understand technology, technological skills, and opportunities to using their knowledgeand skills to solve technological problems. The universal foundations proposed for structuring and organizing thestudy of technology in technology education programs are processes, knowledge, and contexts (ITEA, 1996). This same focus on acquiring technological knowledge, skills/ processes, and the ability to transfer skills/ knowledge to new contexts would seem to be important to structuring instructional delivery in technology teacher education.

The primary focus of the cognitive science 
constructs discussed in this article are increasing the efficiency of learners in converting information and experience into learning, enhancing retention of learning, enhancing transfer of knowledge and skills to new contexts and situations, and helping students takegreater responsibility for their own learning. Thesegoals would seem to be closely related. Johnson (1992a) identified several areas in cognitive science that should be of particular interest to technology educators:

- M ental models, graphic organizers, and other learning aids designed to help students link prerequisite knowledge or schema to new knowledge and experiences.

- M etacognition.

- Situated cognition, and other aspects of cognitive apprenticeship, particularly cognitive modeling.

Each of these cognitive science constructs or techniques enhances learning or transfer of learning to new applications or contexts. The responses to my survey suggest that many technol ogy teacher educators support J ohnson's suggestion that many cognitive science theories and related instructional techniques are very closely aligned with technology education and itstraditional emphasis on experiential learning.

To what extent are the theories of cognitive science embraced, integrated, and taught by technol ogy teacher education programs?

0 ne respondent to this survey observed that there is an important distinction between knowing about cognitive science concepts and deliberately implementing cognitive science theory. This aptly describes the situation reported in the survey responses. While $48 \%$ to $80 \%$ of the responding educators described the top five constructs as essential or very important, only $35 \%$ to $58 \%$ indicated that technology teacher education students learn about these concepts to the extent that they practice or become proficient in their use. Further, theseconceptswere routinely integrated into or modeled during faculty instruction in $35 \%$ to $61 \%$ of theprograms. Thisrelationship for the five least favored cognitive science constructs ( $24 \%$ to $47 \%$ identifying concepts as essential or very important) and levels of learning (13\% to $39 \%$ providing students with opportunities to practice or become proficient in use of concepts). Instances of integration and lor modeling show even larger relative differences with $6 \%$ to $33 \%$ of the programs indicating that these concepts were routinely integrated into or modeled during faculty

instruction. Clearly thereis a differencein levels of knowing and doing in teacher education programs, just as there are differences in perceptions of importance and the frequency that faculty model or integrate concepts into their own instruction.

To what extent should thetheories of cognitive science be embraced, integrated, and taught by technology teacher education programs?

I found that many teacher educators rank many of these cognitive science constructs as essential or very important in training technology education teachers who are preparing to teach thehands-on/minds-on approach to technology education. Well over one half of all respondents rated visualization, situated cognition, coaching, and modeling cognitive processes as essential or very important.

The participants' perceptions of preparation of technology teachers in rank order of importance from most to least important resulted in the following:

1. Visualization

2. Situated cognition

3. Coaching

4. Cognitive modeling

5. Reflection and debriefing

6. Concept mapping

7. Cognitive apprenticeship

8. M etacognition

9. Scaffolding

10. Schema theory

N ote that several of the constructs Johnson (1992a) highlighted as of particular interest to technology education, specifically mental models, visual or graphic organizers, schemata, and metacognition, were ranked among the lowest in importanceby theseteacher educators.

It is regrettable that little change in the conditions that Johnson had reported in 1992 were found. Now, as then, the concepts and techniques that have emerged from cognitive science research appear to have great potential for enhancing the study of technology at all levels and yet the number of authors studying and writing about these ideas in technology education and/or other related technical education contexts during the last decade can still be easily counted on your fingers.

Dr. Dan Brown is an Associate Professor and Coordinator of $G$ raduateStudiesin theD epartment of Technology at IllinoisState University. Heis an Epsilon Pi Tau member-at-large 


\section{References}

Bell, T. P. (Ed.). (1998-1999). Industrial teacher education directory. Millersville, PA: CTTE and N AITTE, Department of Industry and Technology, Millersville University of Pennsylvania.

Berryman, S. E. (1999). N ew York: Teachers College Columbia University. Retrieved August 1999 from theWorld W ideWeb: http://www.ilt.columbia.edu/k12/livetext/docs/berryl.html

Boud, D., Keogh, R., \& Walker, D. (1985). Promoting reflection in learning: A model. In D. Boud, R. Keogh, \& D. Walker (Eds), Reflection: Turning experienceinto learning (pp. 18-40). N ew York: N ichols.

Brewer, W. F., \& Nakamura, G. V. (1984). Thenatureand functions of schemas. In P. E. M orris (Ed.), H andbook of sodial cognition (pp. 110-160). Hillsdale, NJ: Erlbaum.

Brown, J. S., Collins, A., \& Duguid, P. (1989). Situated cognition and the culture of learning. Educational Reercher, 18(1), 32-42. Burnard, P. (1988). Experiential learning: Sometheoretical considerations. International Journal of LifelongEducation, 7(2), 127-133.

Cash, J. R., Behrmann, M . B., Stadt, R. W., \& D aniels, H . M . (1996). Effectiveness of cognitive apprenticeship instructional methods in college automotivetechnology classrooms. Journal of Indusrial Teacher Education, 34(2), 29-49.

Collins, A. (1989). Cognitiveapprenticeship and instructional technology (Technical Report N 0. 474). Champaign, IL: University of Illinois at U rbana-Champaign, Center for theStudy of Reading.

Collins, A., Brown, J. S., \& N ewman, S. E. (1989). Cognitiveapprenticeship: Teeching thecraft of reading, writing, and mathematics (Technical Report N o. 403). CambridgeM A: Bolt, Beranck, \& N ewman. (ERIC D ocument Reproduction ServiceN 0. ED 284 181)

deKleø, J., \& Brown, J. S. (1981). M ental models of physical mechanisms and their acquisition. In J. R. Anderson (Ed.), Cognitiveskillsand ther acquistion (pp. 285-309). H illsdale, NJ: Erlbaum.

Dewey, J. (1938). Education and experience. N ew York: Collier Books.

Dewey, J. (1956). School and society. Chicago: University of Chicago Press.

International Technology Education Association. (1996). Technology for all Americans A rationaleand stucturefor thestudy of technology. Reston VA: International Technology Education Association and theTechnology for all Americans Project.

Johnson, S. D. (1992a). Cognitivescienceand technology education. Paper presented at the 79th M ississippi Valley Industrial Teacher Education conference, Chicago.

Johnson, S. D. (1992b). A framework for technology education curricula which emphasizesintellectual processes. Journal of Technology Education, 3(2). Retrieved August 1999 from the World Wide Web: http://scholar.lib.vt.edu/ejournals/JTE/v3n2/html/johnson.html

Johnson, S. D. (1995). Transfer of learning. TheTechnology Teacher, 54(7), 33-35.

Johnson, S. D ., \& Thomas, R. (1992). Technology education and the cognitive revolution. TheTechnology Teacher, 51(4), 7-12. Kelley, H. H . (1972). Causal schemata and the attribution process. In E. E. Jones, D. E. Kanouse, H. H. Kelley, R. R. N isbett, S. Valins, \& B. Weiner (Eds), Attribution: Perceiving thecauses of behavior (pp. 151-174). M orristown, NJ: General Learning Press Kelley, H. H ., \& M ichela, J. L. (1980). Attribution theory and research. Annual Review of Psychology, 31, 457-501.

Kolb, D. D . (1984). Experiential learning. Experienceasthesourceof learning and development. Englewood Cliffs, NJ: PrenticeH all.

Phillips, J. S., \& Lord, R. G . (1982). Schematic information processing and perceptions of leadership in problem solving groups. Journal of Applied Psychology, 67(4), 486-492.

Satchwell, R. E. (1996). Using functional flow diagrams to enhancetechnical systems understanding. Journal of Industrial Teacher Education, 34(2), 50-81.

Schell, J. W., \& Black, R. S. (1997). Situated learning: An inductive case study of a collaborativelearning experience. Journal of Industrial Teacher Education, 34(4), 5-28.

Stern, D. (1998). Situated learning in adult education (ERIC Digest N O. 195, ED 418250). Retreived from theWorld Wide Web: http://www.ed.gog/databases/ERIC_D igests/ed418250.html

Walter, G. A., \& M arks, S. E. (1981). Experiential learning and change Theory, design, and practice N ew York: Wiley.

West, C. K., Farmer, J. A., \& Wolff, P. M . (1991). Instructional design-Implicationsfrom cognitivescience Englewood Cliffs, NJ: Prentice Hall.

Whetstone, T. S. (1995). Enhancing psychomotor skill development through the use of mental practice. Journal of Industrial Teacher Education, 32(4), Retrieved August 1999 from the World W ide Web: http://scholar.lib.vt.edu/ejournals/J ITE/v32n4/whetstone.html

Whitehead, A. N . (1929). Theaims of education. N ew York: M acmillan.

Wyer, R. S. (1981). An information-processing perspective on social attribution. In J. H. H arvey, W. Ickes, \& R. R. Kidd (Eds.), N ew directionsin attribution research (Vol. 3, pp. 359-404). HillsdaleN J: Erlbaum. 